\title{
Reproductive Characteristics of Captive Greater Rhea (Rhea americana) Males Reared in the State of São Paulo, Brazil
}

\section{author(s) \\ Góes PAA \\ Cavalcante AK da S \\ Nichi M \\ Perez EG de A \\ Barnabe RC \\ Barnabe VH}

Department of Animal Reproduction

School of Veterinary Medicine and Animal

Science

University of São Paulo

Funding: FAPESP N. 99/10326-1

\section{Mail Address}

Paola A. A. Góes

Av. Prof. Dr. Orlando Marques de Paiva, n. 87

FMVZ, Cidade Universitária

05.508-900. São Paulo, SP, Brazil.

E-mail:pgoes@usp.br

\section{Keywords}

Captive animals, semen collection, Rhea.

\section{ABSTRACT}

Rheas (Rhea americana) belongs to the ratite group. Considering the commercial significance of this birds, some techniques, such as semen collection, were standardized. In this study, 107 male rheas (3 to 4 years of age) reared in commercial farms in the state of São Paulo, Brazil, were used. Semen was collected during the breeding and offbreeding seasons of 2001, 2002, and 2003. Bird hierarchical behavior was observed. Birds were restrained performed using a box and a black hood. Semen was collected by digital pressure on the base of the phallus, which size was measured, and the presence or absence of spiral shape was observed. Immediately after collection, semen samples were evaluated for volume, motility, sperm concentration, and morphology. In a limited number of birds, blood samples were collected to measure testosterone levels. Among the 69 birds studied during the breeding season, 44 presented large phalluses, out of which 26 showed spiral shape. The method of semen collection was efficient. The following semen parameter results were obtained: volume $(0.68 \pm 0.14 \mathrm{ml})$, motility $(61.11 \pm 11.54 \%)$, sperm concentration $\left(3.29 \pm 1.33 \times 10^{9} \mathrm{sptz} / \mathrm{ml}\right)$, and number of spermatozoa per ejaculate $\left(2.40 \pm 1.38 \times 10^{9} \mathrm{sptz} / \mathrm{ml}\right)$. Morphological abnormalities were analyzed and recorded. Testosterone levels were statistically different $(p=0.0161)$ between the breeding and non-breeding season $(53.28 \pm 18.41 \mathrm{ng} / \mathrm{ml}$ and $5: 57 \pm 3.81 \mathrm{ng} / \mathrm{ml}$, respectively). Variations in phallus size were also found between the breeding and non-breeding seasons. Larger phalluses and higher testosterone levels were correlated with dominant behavior. The results of the present experiment confirmed that it is possible to collect semen from rheas, allowing the future use of biotechnologies such as artificial insemination.

\section{INTRODUCTION}

The greater rhea (Rhea americana) is considered the largest Brazilian bird (De Cicco, 2001). The native range of this flightless running bird is the plains of South America from Brazil to southern Argentina.

Ratite farming is considered an option to produce alternative livestock in Europe and North America. Still classified as a wild bird, the rhea is currently endangered due to hunting and/or replacement of native vegetation by crops and pastures (Giannoni, 1996). Commercial production of the greater rhea is a viable activity that generates meat, oil, leather, eggs, feathers, and liver protein extract (Giannoni, 1996, Mello, 1987).

The reproduction of captive rheas is currently performed by natural breeding. In Brazil, due to low technology applied, the average fertility rate is below $50 \%$ (Giannoni, 1996).

Low fertility in ratites may be associated to several causes, including behavioral, environmental, seasonal, anatomical, and nutritional factors. 
Góes PAA, Cavalcante AK da S, Nichi M, Perez EG de A, Barnabe RC, Barnabe VH

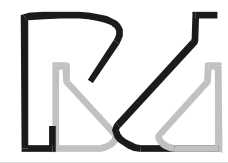

According to Hicks-Alldredge (1996), the main cause of poor fertility is the male. An alternative to improve fertility is the rational use of selected breeding, along with the use of biotechnology, with emphasis on artificial insemination.

Furthermore, even on farms where assisted reproduction techniques are employed, due to the low genetic variability, the degree of inbreeding is high. Therefore, the development of techniques such as semen cryopreservation and artificial insemination would greatly improve productivity in rhea, particularly in Brazil, which has the largest wild population and the highest number of subspecies (Giannoni, 1996).

\section{MATERIAL AND METHODS}

This experiment was performed in the state of São Paulo in 2001, 2002, and 2003. Adult (3 to 4 years of age) male captive rheas (Rhea americana) raised in a semi-intensive system were used.

Birds were fed an ostrich commercial feed (breeding and maintenance phase - $350 \mathrm{~g}$ daily/bird) and grazed on pasture.

The following parameters were assessed at the beginning and end of breeding season according protocol described by Codenotti et al. (1995): male behavioral changes, establishment of harems, nestbuilding by males, presence of fertile eggs in the nest, and presence of sperm cells in the collected material; in females, gentleness and acceptance of the male were observed.

A black cloth hood and an adapted wooden box (Figure 1) were used for visual and physical restrains, respectively.

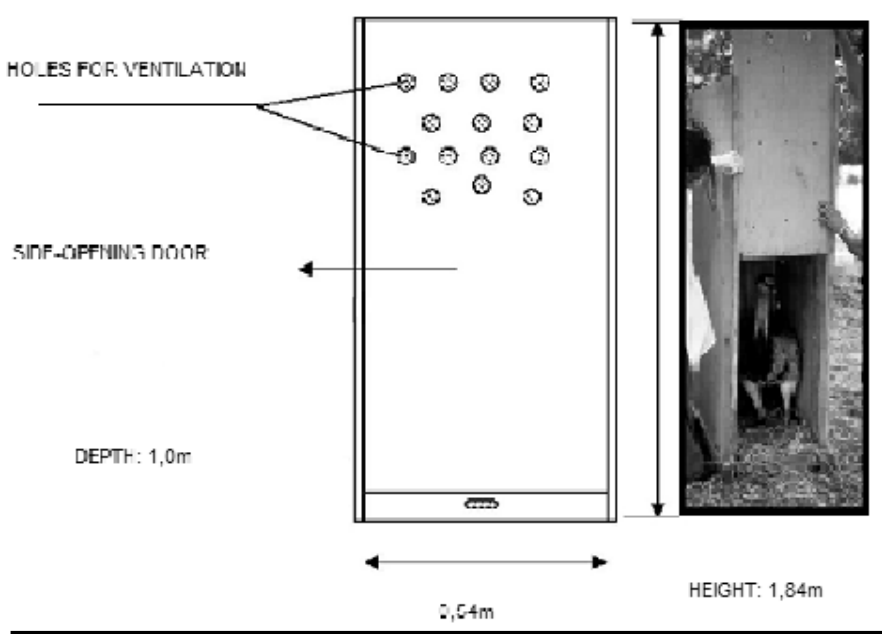

Figure 1. Restraining box used for the collection of semen of greater rheas.
Reproductive Characteristics of Captive Greater Rhea (Rhea americana) Males Reared in the State of São Paulo, Brazil

Semen collection was performed by the gloved-hand technique in the cloacal region. The phallus was exposed by eversion of the opening of the cloacal region (Figuresd 2 and 3). Subsequently, the phallus was inspected and measured. After this procedure, erection was achieved by digital manipulation on the basis of the phallus. Semen was collected in a Petri dish placed on the farthest portion of the phallus, where the semen flowed through the phallic groove. The ventral neck of the bird was sometimes massaged to facilitate ejaculation.

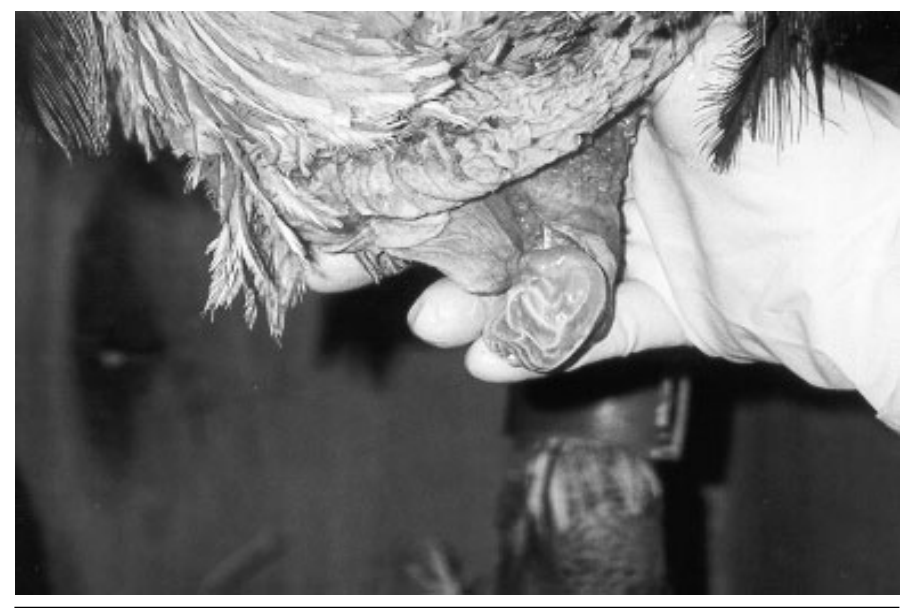

Figure 2. Phallus eversion and massage.

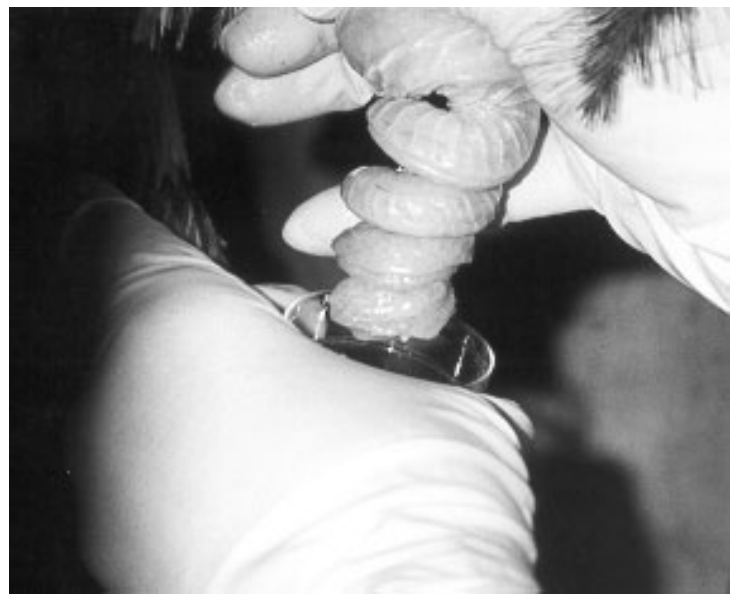

Figure 3. Phallus exposed and semen collection on a Petri dish.

Once collected, semen samples were immediately analyzed for volume and motility. Semen aliquots were fixed in formalin buffer solution for later analysis of sperm concentration and morphology. Acrosomal morphology was evaluated by mixing $10 \mathrm{~L}$ fresh semen and 10 L Fast Green / Rose Bengal dye (Pope; Zhang; Dress, 1991), and smearing the solution on a glass slide.

Blood samples were collected from the medial metatarsal vein to measure testosterone plasma levels. 


\section{Góes PAA, Cavalcante AK da S, Nichi M, Perez EG de A, Barnabe RC, Barnabe VH}

Data were analyzed using the SAS System for Windows (SAS Institute, 2000). Results are presented as means standard errors. Pearson's and Spearman's correlation tests were applied to calculate the relationship between parametric and non-parametric variables, respectively.

\section{RESULTS AND DISCUSSION}

One hundred and seven birds were handled: 69 during the breeding season and 38 during the offbreeding season. No sperm cells were observed in the samples collected during the off-breeding season. The ejaculate of 46 out of 69 birds presented sperm cells. In 19 samples, the presence of contamination (i.e., feces and/or urine) impaired semen evaluation. In that case, samples were discarded (Figure 4)

The breeding seasons observed in the present study ranged from July to October of 2001, May to November of 2002, and July to late November of 2003. These seasons occurred in a different period from those reported in literature, which state that the breeding season in the southeastern region of Brazil usually begins by the end of August and extends until the end of February (Codenotti, 1997).

Male aggressive behavior towards other males and handlers were considerably different among birds. Moreover, nest-building and the presence of fertile eggs were observed, consistent with the data found in the literature (Codenotti \& Alvarez, 2001; Codenotti \& Berninca Alvarez, 1995; Giannoni, 1996). The breeding seasons were also confirmed by the presence of sperm cells in the collected semen samples.

The dominant male was identified by the following behaviors: aggressiveness, when the bird fluttered its wings, dangling and vibrating them nervously;
Reproductive Characteristics of Captive Greater Rhea (Rhea americana) Males Reared in the State of São Paulo, Brazil vocalization; and protective behavior towards the female.

During the periods of harem establishment (May 2002 and July 2001 and 2003), male vocalization, trying to draw females' attention, was frequently observed. Mercolli and Yanosky (1994) demonstrated that vocalization in male rheas can be observed between the months of August and October. According to these authors, this behavior is performed to attract the females.

An harem usually presented a ratio of 1 male to 59 females. Once established, the males showed strong territorial behavior, followed by mating and nestbuilding. Each group could have more than one dominant male. These observations are consistent with previous studies on the behavior of rheas in Rio Grande do Sul, carried out by Codenotti, Beninca \& Alvarez (1995) and Codenotti \& Alvarez (2001).

Hemberger, Hopes \& Bostedt (2001) restrained ostriches by covering their head with bag of soft tissue. This allowed semen collection because the birds remained static. In the present experiment, it was necessary to use both a black hood to cover the birds' head and a wooden restraining box to achieve better results.

The semen collection technique used in the present study was adequate to collect semen in rheas. During collections, some birds presented an erect phallus. This was usually accompanied change in the shape of the final portion of the Phallus, which became spiraled. Some birds also vocalized at the moment of ejaculation. The effectiveness of this method of semen collection was also verified in ostriches (Hemberger; Hopes; Bostest, 2001), parrots (Brock, 1991), roosters (Benoff et al., 1981), and turkeys (Burrows, Quinn, 1935). A recent study demonstrated the applicability of the use artificial vagina for semen collection in emus (Malecki, Martin, Lindsay, 1997a). However, this technique requires conditioning, which was not the case of the present experiment. Semen collection using massage allows semen collection in wild animals, which enables increasing genetic diversification in captive populations.

Semen samples of 69 animals were collected 


\section{Góes PAA, Cavalcante AK da S, Nichi M, Perez EG de A, Barnabe RC, Barnabe VH}

Reproductive Characteristics of Captive Greater Rhea (Rhea americana) Males Reared in the State of São Paulo, Brazil during the breeding season using that technique. Spermatozoa were observed in 46 samples. These results demonstrate the efficiency of this technique for semen collection in rheas (66\%).

Forty four birds handled during the breeding season presented large phalluses (larger than $3 \mathrm{~cm}$ ) and 25 animals showed small ones (less than $3 \mathrm{~cm}$ ). During the off-breeding season, phallus size of all birds remained small. Spiral formation was observed in 26 animals during the breeding season (59\%), and only in birds presenting large phalluses.

Ejaculate volumes were considerably different among samples, ranging between 0.5 and $1.0 \mathrm{ml}$, with an average of $0.68 \mathrm{ml}$. Similar results were found in previous studies with emus $(0.61 \mathrm{~mL}$; Malecki; Martin, Lindsay, 1997b) and ostriches (0.64 mL; Hemberger; Hopes; Bostesdt, 2001).

Sperm concentrations also varied among the collected ejaculates, ranging from 1.24 to $6.88 \times 10^{9}$ sperm $/ \mathrm{ml}$, with an average concentration of $3.29 \times 10^{9}$ sperm $/ \mathrm{ml}$. Similar results were found in emus $\left(3.34 \times 10^{9}\right.$ sperm/ml; Malecki, Martin; Lindsay, 1997b) and ostriches (7.3 ×109 sperm/ml; Hemberger; Hopes; Bostest, 2001). Average number of sperm per ejaculate determined in semen of rheas was 2.40 billion cells $/ \mathrm{ml}$. Hocking (1989) obtained averages of 1.36 and 2.37 x10 $1{ }^{\circ}$ sperm $/ \mathrm{ml}$ in 25- and 60-week-old Cobb-500 cockerels, respectively. Rosenstrauch, Egen \& Fredländer (1994) observed averages of 3.4 and 0.8 $\times 10^{9} \mathrm{sperm} / \mathrm{ml}$ in 32- and 110-week-old Cornish cockerels, respectively. The number of sperm per ejaculate reflects more precisely the sperm production capacity in cockerels, considering that a lower seminal volume may be compensated by a higher sperm concentration (Amann, 1999).

Sperm motility values found in the present study varied from 40 to $80 \%$, with an average of $61.1 \%$. These values were lower than those found in ostriches (78\%) described by Hemberger, Hopes, and Bostedt (2001). Bertschinger et al. (1992) suggested that sperm motility in ostriches is lower as compared to mammals.

To our knowledge, this is the first report on sperm morphological abnormalities in rheas, and thus, a comparison with previous studies was not possible. It was also difficult to classify sperm abnormalities, and therefore, parameters of sperm evaluation developed for domestic fowl were used. Sperm morphology was similar to ostriches, with sperm showing a cylindrical shape divided in head, midpiece, and tail (Figures 5 and 6). The head has a very evident acrosome; the tail consists of a main piece and end piece.

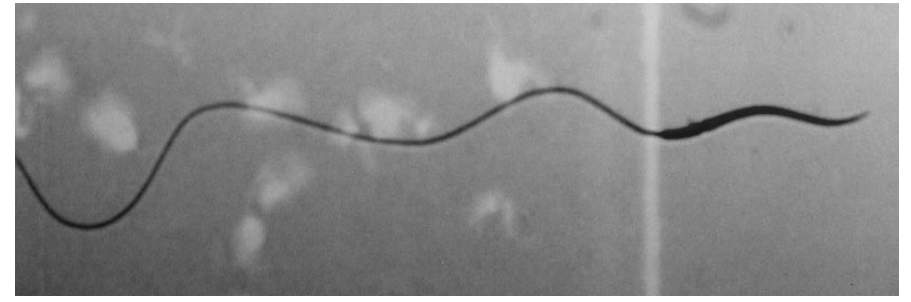

Figure 5. Optical microscopy of Rhea spermatozoa (1000x magnification).

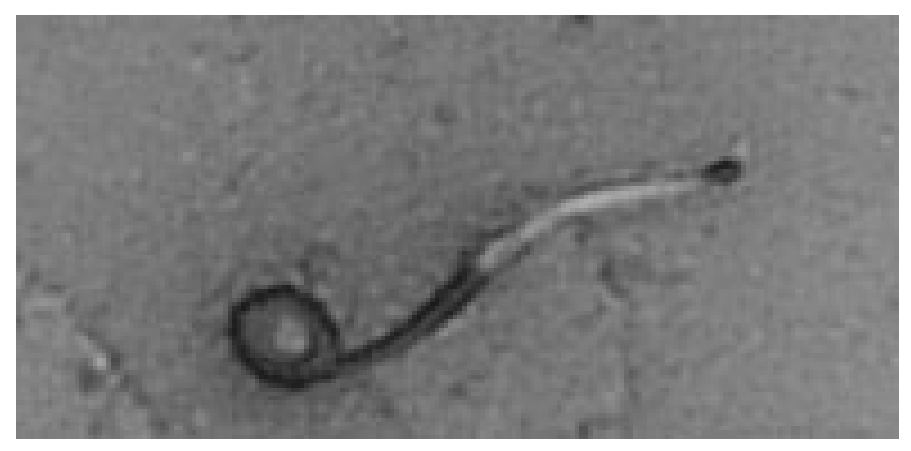

Figure 6. Tail abnormality of a rhea spermatozoon. Optical microscopy, 1000x magnification.

The analysis revealed wide variety of morphological changes, such as bent head, folded tail, strongly folded tail, strongly coiled tail, coiled tail, retroaxial insertion. Celeghini (2000) described some sperm morphological abnormalities in cockerels, such as acrosome, head, midpiece, and tail defects, protoplasmic droplets, isolated heads, and teratological abnormalities, similar to those found in rheas in the present study. The staining methods of Williams and Fast Panótico $4^{\circledR}$ used for the morphological evaluation were efficient; however, the first stained the cells more clearly, improving the identification of morphological abnormalities. The Fast Green / Rose Bengal staining (Pope, Zhang, Dress, 1991), used with fresh semen, clearly highlighted rhea sperm acrosome in a dark violet color. Some problems were found when using vacuum blood collection tubes (Vacutainer ${ }^{\circledR}$ Systems). During collection, the restraining technique still allowed the bird some leg movements, and whenever that happened, the tube lost the vacuum. Therefore, 30X8 $\mathrm{mm}$ needles were manually arched and coupled to 5$\mathrm{ml}$ syringes. Birds with large phalluses had higher testosterone levels as compared to those with smaller phalluses (Table 1).

Plasma testosterone levels were statistically different $(p=0.0161)$ between the breeding and the off-breeding seasons $(53.28 \pm 18.41 \mathrm{ng} / \mathrm{ml}$ and 5.57 


\section{Góes PAA, Cavalcante AK da S, Nichi M, Perez EG de A, Barnabe RC, Barnabe VH}

Reproductive Characteristics of Captive Greater Rhea (Rhea americana) Males Reared in the State of São Paulo, Brazil $\pm 3.8141 \mathrm{ng} / \mathrm{ml}$, respectively). These results agree with previous studies in emus raised in south-eastern Australia, where differences were also found in serum testosterone levels between the breeding and the offbreeding seasons $(2.5$ to $6.0 \mathrm{ng} / \mathrm{ml}$ and 0.5 to $1.0 \mathrm{ng} /$ $\mathrm{ml})$, respectively. According to Bertschinger et al. (1991), plasma testosterone levels in ostriches reared in South Africa decrease one month after the breeding season, reaching maximum values (461 nmol 1-1) during the breeding season and minimum levels (63 nmol 1-1) during the off-breeding season. These results may explain the inability of finding sperm cells in the ejaculate collected from birds outside the breeding season in the present experiment, as sperm production is dependent on testosterone (Codenotti, 1997).

\begin{tabular}{cccc}
\hline \multicolumn{4}{c}{ Table $\mathbf{1}$ - Plasma testosterone levels (TESTO, $\mathrm{ng} / \mathrm{ml})$, phallus } \\
size, and presence of sperm in semen samples collected from \\
four captive rheas (Rhea americana) during the breeding season. \\
\hline Sample & TESTO $(\mathbf{n g} / \mathbf{m L})$ & Phallus size & Spermatozoa \\
\hline 1 & 3.65 & Large & Present \\
2 & 0.13 & Small & Absent \\
3 & 0.59 & Small & Absent \\
4 & 3.26 & Large & Present \\
\hline
\end{tabular}

Table 2 - Correlation analysis and level of significance (p) between ejaculate volume (VOL), motility (MOT), sperm concentration (CONC), number of spermatozoa (NUM), plasma testosterone levels (TESTO).

\begin{tabular}{lccccc}
\hline $\mathbf{r}^{2}$ & VOL & MOT & CONC & NUM & TESTO \\
$\mathbf{p}$ & & & & & \\
\hline VOL & 1.000 & 0.719 & 0.873 & 0.922 & 0.938 \\
& & 0.1069 & 0.0229 & 0.0088 & 0.0056 \\
MOT & & 1.000 & 0.841 & 0.802 & 0.742 \\
& & & 0.0356 & 0.0546 & 0.0910 \\
CONC & & & 1.000 & 0.989 & 0.960 \\
& & & & 0.0002 & 0.0024 \\
NUM & & & & 1.000 & 0.989 \\
& & & & & 0.0002 \\
TESTO & & & & & 1.000 \\
\hline
\end{tabular}

The correlations found between plasma testosterone level and both sperm concentration and number (Table 2) have also been found in other species. This correlation may be explained by the fact that sperm production depends on testosterone levels. High levels of plasma testosterone are necessary to stimulate spermatogenesis (Hafez \& Hafez, 2004). The correlation between semen volume and testosterone may explain the significant increase in testes size. The consequent increase in parenchymal volume and in the number of Leydig cells, responsible for testosterone production, would lead to higher sperm production. Rhea semen parameter results obtained in the present study may contribute for the dissemination of the use of biotechnology, for commercial and conservational purposes in the future.

\section{CONCLUSIONS}

1. The technique of digital massage of the base of the phallus allowed easy collection semen from rheas.

2. The collected samples provided information on the semen characteristics of this species.

\section{REFERENCES}

Amann RP. Lessons for the poultry industry gleaned from experiences with other commodity species. Poultry Science 1999; 78(3):419-427.

Bertschinger HJ, Burger WP, Solely JT, De Lange JH. Semen collection and evaluation of the male Ostrich. Proceedings of the Congress of the South African Association Veterinay; 1992; Grahamstown. p.154-158.

Brock MK. Semen collection and artificial insemination in the hispaniolan parrot (Amazona ventral). Journal of Zoo and Wildlife Medicine 1991; 22(1):107-114.

Benoff FH, Rowe KE, Fuquay JI, Renden JA, Arscott GH. Effect of semen collector on sperm concentration and semen volume in broiler breeder males. Poultry Science 1981; 60(5):1062-1065.

Burrows WA, Quinn J P. The method of obtain Spermatozoa from the domestic fowl. Poultry Science 1935; 14(4):251-254.

Codenotti T, Alvarez F. Mating behavior of the male Greater Rhea. Wilson Bull 2001; 113(1):85-89.

Codenotti TL, Beninca D, Alvarez F. Ethogram of the behavior and relations with the habitat and with age in the Nandu (Rhea americana). Vertebrate Acta 1995; 22:1-2.

Codenotti TL. Reproductive phenology and biometry of nests, eggs and Pollos del Nandu, Rhea americana in Rio Grande do Sul, Brazil. El Elkrema 1997; 4:211-223.

Giannoni ML. Emus and ostriches: an alternative for the farmer. Jaboticabal: FUNEP; 1996. 49 p.

Hafez ESE, Hafez B. Animal breeding. 7th ed. Barueri: Manole; 2004. $513 \mathrm{p}$.

Hemberger MY, Hopes R, Bostedt H. Semen collection, examination and spermiogram in Ostrich. Reproduction in Domestic Animal $2001 ; 36: 241-243$

Hicks Alldredge KD. Ratite reproduction. In: Tully TN, Shan SM. Ratites: management, medicine and surgery. Malabar: Krieger Publishing Company; 1996. 188 p. 
Hocking PM. Effect of dietary crude protein concentration on semen yield and quality in male broiler breeder fowls. British Poultry Science 1989; 30:935-945.

Malecki IA, Martin GB, Lindsay DR. Semen production by the Emu (Dromaius novaehollandiae). 1. Methods for collection of semen. Poultry Science 1997a; 76:615-621.

Malecki IA, Martin GB, Lindsay DR. Semen production by the male emu (Dromaius novaehollandiae). 2. Effect of collection frequency on the production of semen and spermatozoa. Poultry Science 1997b; 76:622-626.

Mello NH. A summary of the man: Ema. Globo Rural 1987; 20: 5660.

Pope CE, Zhang YZ, Dress BL. A simple staining method for evaluating status of cat acrossomal Spermatozoa. Journal of Zoo and Wildlife Medicine 1991; 22(1):87-95.

De Cicco LHS. Animal health. Ema. It is created by the father [cited 2001 jan 31]. Available from : http://www.saudeanimal.com.br/ extinto $25 / \mathrm{html}$

Rosenstrauch $A$, Egen $A A$, Friedländer $M$. Spermatozoa retention by Sertoli cells during the decline in fertility in aging roosters. Biology Reproduction 1994; 50:129-136. 